\title{
INNOVATIONS AS A METHOD OF DEVELOPMENT IN THE PERIOD OF LOW OIL PRICES
}

\author{
. . едоров \\ K. M. Fedorov \\ юменский госуд рственный университет, г. юмень
}

лючевые слов : конференция еждун родного обществ инженеров-нефтяников; иннов ционный путь р звития; нефтег зов я индустрия

Key words: International Society of Petroleum Engineers; innovation way of development; oil and gas industry

оскве с 26 по 28 октября прошел междун родный форум по проблем м нефтяной и г зовой промышленности. онференция еждун родного обществ инженеров-нефтяников (SPE Russian Petroleum Technical Conference 2015) уник льн тем, что собир ет предст вителей р зных комп ний-опер торов по добыче углеводородов, сервисных и иннов ционных подр зделений из оссии и из-з рубеж для обсуждения кту льных проблем и н пр влений р звития нефтег зового сектор .

огд последняя конференция з думыв л сь и пл ниров л сь, гл вн я проблем 3 ключ л сь в истощении з п сов, обсужд лись сцен рии р звития обществ в эпоху рост цены и снижения потребления углеводородов. изнь р спорядил сь по-другому, и гл вным мотивом обсуждения ст л вопрос низких цен н нефть и выжив ния промышленности в этих условиях.

ерв я же плен рн я сессия обозн чил эту проблему. редсед тель SPE обществ эйт н иэн сформулиров л три сост вляющие выход из сложившейся ситу ции: внедрение иннов ционных подходов и технологий, экономичный подход к 3 тр т м и решение вопросов экологии при поним нии, что энергетические потребности обществ реш ются и будут реш ться в ближ йшее время в основном 3 счет использов ния углеводородов.

иректор комп нии Statoil оссия оргейр юдл н р сск 3 л о политике комп нии в сложное время низких цен н нефть. ктик комп нии сводится к упрощению технических решений («лучшее - вр г хорошего»), повышению культуры экономии з тр т, р зр ботке и внедрению иннов ций, позволяющих повысить рент бельность добычи, тр нспорт и перер ботки углеводородного сырья.

птимистично прозвуч л докл д директор российского подр зделения Total

к де у ссезон о ре лизуемом совместном проекте строительств 3 вод по производству сжиженного природного г 3 ( ) н м ле в поселке бет . ейч с бет выглядит к к н стоящий северный город, в котором построены порт, эродром (есть регулярные рейсы из осквы комп нии тэйр), зн чительн я ч сть инфр структуры.

р ллельно строительству з вод для производств реш ется з д ч его тр нспорт . помним, что бет н ходится 3 полярным кругом в рском море, где большую ч сть времени море сков но льд ми. ннов ционным решением этой проблемы ст л р зр ботк тр нспортных т нкеров нового тип или ледокольного кл сс . троительство т ких т нкеров для перевозки уже н ч то во р нции.

р мК ми докл д ост лся экономический вопрос о рент бельности т кого пути сн бжения и потенци льных п ртнер х-потребителях тр нспортируемого г 3 .

второй день п нельн я сессия был посвящен и н зыв л сь « т н учной идеи к внедрению технологий». докл д ми выступили предст вители комп ний-пионеров в обл сти иннов ционных $\mathrm{p}$ зр боток. лощ дк конференции был отд н предст вителям колково, иннов ционной комп нии ITF, н ибо- 
лее крупной сервисной комп нии люмберже. оссийскую вузовскую н уку и ее вкл д предст влял им. убкин .

уководитель нефтег зового центр онд « колково» $\mathrm{p}$ т йдуллин презентов л принципы фин нсиров ния иннов ционных р зр боток и р сск 3 л о некоторых текущих проект х, фин нсируемых ондом. еобходимо отметить, что отбор проектов в онде ведется не с точки зрения кту льности их для нефтег зового сектор , по степени осуществимости проект и, гл вное, возможности его ре лиз ции н пр ктике. ледов тельно, з д ч концентр ции интеллекту льных усилий и творческих возможностей для решения кту льной проблемы в p мк х онд ст новится проблем тичной.

б опыте р зр ботки кту льных иннов ционных решений, интересующих p зные, ч сто конкурирующие комп нии, р сск 3 л трик , p йен, генер льный директор комп нии ITF. ост точно ч сто комп нии, специ лизирующиеся в одной обл сти, н пример добыв ющие комп ниИ, 3 интересов ны в решении близких им $з$ д ч. опрос ми подбор $\mathrm{p}$ зр ботчиков иннов ций, их инвестиров ния, юридическими вопрос ми использов ния результ тов будущей р зр ботки комп ниями-уч стник ми проект и другими з д ч ми з ним ется сервисн я комп ния ITF. тметим, об докл дчик конст тиров ли, что успешность иннов ционных р зр боток не превыш ет $30 \%$, то есть менее трети проектов 3 К нчив ются действительным решением проблемы и доходят до промышленности.

иректор московского н учно-исследов тельского центр комп нии люмберже рин улов поделил сь опытом проведения фунд мент льных и прикл дных исследов ний в комп нии. ольш я ч сть исследов ний проводится в специ лизиров нных н учных подр зделениях. сновн я ч сть р зр боток, дошедших до внедрения, выполняется именно т м. истем гр нтов и фин нсируемых н учных проектов, выполняемых вуз ми и к демическими орг низ циями, д ет гор здо меньший результ т.

роректор им. убкин их ил илин р сск 3 л, через к кие орг низ ционные формы проводятся исследов ния в университете. сож лению, тем тики исследов ний, т кие к к водог зовое воздействие, применение полимеров, сшитых по р зным технологиям, не предст вляют иннов ционного прорыв н сегодняшний день. целом вузовск я н ук пок не н шл действенных рыч гов для решения действительно кту льных для нефтег зодобыв ющих комп ний $з$ д ч.

нельн я сессия третьего дня н зыв л сь « ефтем теринские породы: p 3ведк , изучение, технологии добычи углеводородов» и был посвящен 3 п с м сл нцевой нефти или б женовской свите. ти отложения прослежив ются пр ктически н всем протяжении П дной ибири и являются нефтем теринскими 3 леж ми. десь миллионы лет отл г лись и подверг лись воздействию высоких темпер тур и д влений орг нические ост нки, и рожд лись, согл сно орг нической теории, нефть и г з, в д льнейшем и з полнившие ловушки, которые сегодня мы зн ем к к месторождения ренгойское, ов ненковское, мотлорское, монтовское, едоровское и др. о с м 6 женовск я свит предст вляет собой низкопрониц емые глины, $з$ полненные твердым керогеном, битумом и лишь н несколько процентов нефтью, которую мы добыв ем по всей п дной ибири. зпромнефть р сск $з$ л о пл н х р зведки и исследов ний этих нетр диционных 3 п сов углеводородов. месте с тем, пок пл нируются лишь исследов ния общего пл н, кл ссифик ция 3 п сов и другие подготовительные p боты. н призн л, что н сегодня в условиях низких цен н нефть говорить о полноценных р зр ботк х и полном сшт бных исследов ниях технологий вовлечения этой нефти и битум из б жен говорить не приходится, это з д ч з втр шнего дня.

резент ции предст вителей тюменских подр зделений оснефти больше сводились к перечислению современных геофизических и петрофизических методов исследов ния плотных и нетр диционных коллекторов и опыт отечественной ре лиз ции многост дийного н низкопрониц емых коллектор х. ким обр -

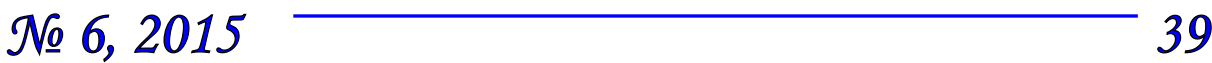


зом, о технологиях полноценного извлечения углеводородных з п сов (включ я битум и углеводородную ч сть кероген ) из $б$ женовских отложений речи пок не идет.

р ллельно с плен рными сессиями шло интересное обсуждение современных подходов и технологий повышения эффективности нефте- и г зодобычи н технических секциях конференции. ного говорилось о мониторинге р зр ботки, втом тизиров нных подход х к н лизу з воднения н уч стк х месторождений, выбору скв жин под и пл ниров нии с мих прогр мм . десь ск зыв ется специфик российских месторождений, в первую очередь в п дной ибири: крупные месторождения с тысяч ми скв жин, где «ручной» подход к н лизу р зр ботки м лоэффективен и не позволяет опер тивно реш ть з д чи р зр ботки и 3 воднения.

конференции было орг низов но обсуждение кту льных проблем нефтег зового сектор в р мк х руглых столов. тметим проблемы, поднятые н руглом столе, посвященном внедрению физико-химических методов увеличения нефтеотд чи пл стов. редст вители российских комп ний конст тиров ли, что в сложное время низких цен н нефть идет ктивное внедрение точечных методов воздействия н скв жины, в которых объемы 3 к чив емых химре гентов сост вляют от десятков до сотен тонн. иболее широко используемыми метод ми являются мероприятия по стимуляции производительности скв жин с помощью

, применение горизонт льных скв жин или сочет ние этих технологий в многост дийном , т кже вошедшие в пр ктику р зр ботки методы выр внив ния профилей приемистости н гнет тельных скв жин и борьбы с обводнением в добыв ющих скв жин х. дной из причин скептического отношения к большеобъемным являются высокие риски и боязнь высоких непроизводительных з тр т. используемым в российской пр ктике метод м повышения нефтеотд чи можно отнести тепловые методы воздействия, хотя рент бельность их внедрения пок ост ется под вопросом.

динственным внедрением большеобъемных оторочек химре гентов ост ется проект комп нии лым етролеум евелопмент по применению -щелочного 3 воднения (ASP), продвиг емого оторочкой р створ полимер , н п днолымском нефтяном месторождении. роект прошел ст дии подбор ре гентов, л бор торных исследов ний и н ходится в ст дии созд ния инфр структуры для опытно-промышленных р бот. ольшеобъемные 3 к чки связ ны с созд нием небольших з водов по очистке воды, смешив нию ре гентов н промысле для под чи их в н гнет тельные скв жины. иски комп нии, связ нные с $з$ тр т ми н предв рительные исследов ния, современную инфр структуру и ре лиз цию с мой технологии, минимизируются тем, что технология н учно обоснов н , 3 п тентов н и пробиров н н пр ктике. ри успешном применении технологии открыв ются широкие возможности ее тир жиров ния, в первую очередь в п дной ибири, где множество сходных по геолого-физическим и фильтр ционным х р ктеристик м месторождений.

3 ключение отметим, что втор не претендует н дет льный н лиз и полный охв т всех тем тик конференции. ля более полной информ ции необходимо обр тится к труд м конференции, р змещенным в электронной библиотеке OnePetro [1].

писок литер туры

1. Technical paper library OnePetro. [ лектронный pecypc]. - ежим доступ : www.spe.org.

ведения об втор $x$

едоров онст нтин их йлович, д. ф.-м. н., профессор, директор изико-технического институт юменского госуд рственного универcumem , тел. 8(982)9303027, e-mail: k.m.fedorov@utmn.ru
Information about the authors

Fedorov K. M., Doctor of Physics and Mathematics, professor, director of Physical and Technical Institute of Tyumen State University, phone: 8(982)9303027, e-mail: k.m.fedorov@utmn.ru 